\title{
INTEGRATED SUPPLY CHAIN MANAGEMENT PROCESS BENCHMARKS FOR GLOBAL BUSINESS SERVICES IN ROMANIA
}

\author{
Diana COZMIUC ${ }^{a^{*}}$ \\ ${ }^{a}$ West University of Timisoara, Romania
}

DOI: $10.24818 / \mathrm{IMC} / 2020 / 01.09$

\begin{abstract}
Over 200 Romanian subsidiaries of global companies provide shared services or global business services. Part of these companies are the most important business process outsourcing companies worldwide. Shared services transition activities as are at home location. Global business services add value by managing integrated processes with information technology support. Global standards for business processes exist in business process management theory and worldclass benchmarks. Part of standard global business processes are related to supply chain management, where the latest global standard in the Supply Chain Operations Reference model SCOR. The goal of this article is to identify the global standards and benchmarks for supply chain management related global business centers according to multiple references. These references cover key theory: supply chain management and business process management and key empirical references: global management consultants, information architecture providers, the most important global business process outsourcing companies. The methodology is an instrumental multiple case study. Results show that supply chain operations certification providers, business process management, management consultants, enterprise resource planning software providers Oracle and SAP, and the leading worldwide global business process outsourcing companies share the process models in SCOR. The study highlights best results begin with SCOR and worldclass process benchmarks, continue with information technology and thereby design global business services. This is an interdisciplinary approach which brings business process acumen to both management theory and management practice.
\end{abstract}

KEYWORDS: integrated supply chain management, business process management, benchmarking, Hackett standards, global business service, advanced automation

\section{INTRODUCTION}

Shared service units have emerged since the 1980s as an application of activity based costing by Kaplan. Repetitive activities organized by activity based costing are the realm of shared service provision, recognized as such by accounting professionals (The Association of Chartered Certified Accountants, 2012). Several activities with a common end are called processes, and may be business processes. Whereas shared services were created to manage standardizable activities, a similar approach to business process organization, via global business services, is provided by Drucker, a proeminent management author who noted the decentralized management of repetitive business processes in dedicated organizations (Drucker, 2017). A business process may often be visualized (modelled) as a flowchart of a sequence of activities with interleaving decision points or as a process matrix of a sequence of activities with relevance rules based on data in the process (Chen \& Tsai, 2010; Kirchmer, 2017a, 2017b). Several types of operational activities are called processes, and may be described by process follow charts and managed by business process

\footnotetext{
* Corresponding author. E-mail address: diana.cozmiuc.record@gmail.com
} 
organizations. Management consultants (Accenture, 2015, 2020a; Deloitte, 2017; EY, 2017, 2020; KPMG, 2016) recognize the operational process expertise of global business service providers. Consultants also claim the advantages of shared service centers are unified location, for example in best cost country; standardized processes; single platform technology solutions; expert personnel. Mc Kinsey (2017b) also argued global business services manage integrated global business processes, and are the contemporary more advanced version of shared services. Global business services (Mc Kinsey, 2017b) manage end-to-end activities across functions. At EY (2020), global business services is the evolution of shared services and business process outsourcing - both focused on process efficiency improvement and cost reduction. It's a key pillar of a digital strategy that helps companies navigate the transformative age. KPMG (2016) global business services are a next generation operational and organizational for enterprises to deliver business processes such as human resources, finance, information technology, customer care to internal and external customers. Global business services (KPMG, 2016) are often applied on a global scale using multiple service delivery models, including outsourcing, shared service unit and cloud platforms. KPMG (2016) refers to the following levels of process maturity: ad-hoc; process visibility; process standardization; process discipline; process driven. For example, Wipro (2020c) argue process centric shared services move, through integration with a company's value chain, to global business services. Customers of global business services retain core management, legal, expertise, product specific processes, while global business services providers manage standardizable processes, technology, competencies in central locations. Deloitte (2017) classify services as the following progressive scale: shared service centers; multiple functions shared service centers; global business services as multiple functions global service management; integrated business services, with service and product lines integrated; service management; global service owners; integrated network. The Hackett (2020a) standards for global business processes are a global benchmark of leading business services. Global business services may be viewed as functions or processes (Hackett, 2020a). The global business processes are: account-to-report processes; enterprise performance management processes; order-to-cash processes (Hackett, 2020c); purchase-to-pay processes (Hackett, 2020d). This article is a comprehensive overview about business process management focused on supply chain management related processes in the standard SCOR model. The goal of this article is to create a comprehensive multi-source theoretical and empirical framework for supply chain management related global business processes. The sources to be considered are theoretical: supply chain management certification providers, business process management scientific authors and empirical: business management consultants, information technology solution providers, the most important global business service providers worldwide and locally in Romania. The article is an instrumental multiple case study. The instrumental nature comes from the prescriptive nature of theoretical business processes to the practice of management consultants, enterprise resource planning solution providers Oracle and SAP and the most important business process organizations worldwide with local Romanian subsidiaries. The article uses a wide variety of references from several types of references, theoretical and empirical. The findings are consistent, that best process models in supply chain management activities exist, and are especially important to global service providers who act as process experts. Whereas market research shows Romania is home to a large number of shared service providers, leading worldclass business process outsourcing companies work towards best practices and standards supported by consultants and enterprise resource planning solutions. Process expertise becomes the source of value add in these organizations. Process expertise is benchmarked by both business consultants and business process solution providers. Consensus exists amongst process management theory, best practice standards provided by management consultants, enterprise resource planning solutions provided by Oracle and SAP, the practice of the best business process outsourcing service providers that business process models and benchmarks are useful. The article serves business process modelling in theoretical tools and empirical tools such as management consultants' benchmarks, enterprise resource planning functionality, business process outsourcing service providers’ benchmarks. 


\section{THEORY - INTEGRATED SUPPLY CHAIN MANAGEMENT DEFINITION, ACTIVITIES AND PROCESS FLOW}

In the 2010-2020 decade, in manufacturing, integrated supply chain planning has described the overview of manufacturing decisions, activities and processes. Integrated supply chain management is the most advanced form of supply chain management (Borges, 2015; Creazza et al., 2010; Dag \& Hulthen, 2012; Kumar \& Nambirijan, 2013; O’Brian, 2012; PWC, 2013; Roh, 2011; Von Haartman \& Bengtsson, 2015). An integrated supply chain has four levels of maturity (PWC, 2013): level 1, reactive supply chain management; level 2, internal supply chain integration with planned buffers; level 3, collaboration across extended supply chain network; level 4, dynamic supply chain adaption and flexibility. This is the latest version of manufacturing technology, with end-to-end integration in the supply chain - from customer order until all tiers in the supply chain (Kagermann et al.., 2013). It reflects the most advanced manufacturing technology and related business processes (Kagermann et al.., 2013). In the manufacturing version of the digital enterprise, digital transformation will replace the automation pyramid with the digitalization network. This is the Industry 4.0 scenario. Industry 4.0 is built on the following prerequisites: vertical integration, endto-end integration, horizontal integration. Vertical integration and networked manufacturing systems describe the intelligent crosslinking and digitalization within the different aggregation and hierarchical levels of a value creation module (Kagermann at al., 2013). End-to-end integration describes the intelligent cross linking and digitalization throughout all phases of a product lifecycle: from the raw material acquisition to manufacturing system, product use, product end of life (Kagermann et al.., 2013). Horizontal integration across the entire value creation network describes the cross company and company internal cross-linking and digitalization of value creation modules throughout the value chain of a product lifecycle and between value chains of adjoining product lifecycles (Kagermann et al.., 2013). In integrated enterprise management, Product Lifecycle Management software, Customer Relationship Management, Supply Chain Management, Enterprise Resource Planning form the enterprise architecture.

Supply Chain Management is defined as the handling of the flow of goods and services from the raw manufacturing of the product through to the consumption by the consumer (AIMS, 2020; The Chartered Institute of Logistics and Supply Chain Management (CILSCM global), 2020; Chartered Institute of Procurement and Supply, 2020; Chartered Institute of Supply Chain Management, 2020; Council of Supply Management Professionals, 2020; International Society of Supply Chain Professionals, 2020; International Supply Chain Education Alliance, 2020; Supply Chain Council, 2010; Supply Chain Management Review, 2020). In manufacturing industries, global integrated supply chain management is the most advanced form of automation technology and the state that shows the readiness to transition to digitalization. The classic reference integrated supply chain management model is SCOR, an acronym for the Supply Chain Operations Reference model. The SCOR model was developed in 1996 by the management consulting firm PRTM and A. It has been updated in several versions since. Supply Chain Management Operations Reference model entails several standard process models for all supply chain management scenarios. The SCOR model in the entire supply chain remains the model for 2019 (Association for Supply Chain Management, 2019, 2020).

Supply chain management activities include: planning, sourcing, making, delivering, returning (AIMS, 2020; The Chartered Institute of Logistics and Supply Chain Management, 2020; Chartered Institute of Procurement and Supply, 2020; Council of Supply Management Professionals, 2020; Demand Driven Institute, 2020a, 2020b; International Supply Chain Education Alliance, 2020; Institute for Supply Chain Management, 2020; International Society of Supply Chain Professionals, 2020; Supply Chain Management Review, 2020; Tech Target, 2020).

According to these views, planning may be the configuration of the supply chain; the activities associated with developing plans to operate the supply chain; the gathering of requirements, 
gathering of information on available resources, balancing requirements and resources to determine planned capabilities and gaps in demand or resources and identify actions to correct these gaps.

Sourcing means identifying, evaluating and building relationships with suppliers; processes associated with ordering, delivery, receipt and transfer of raw material items, subassemblies, product and/or services. This is the source to order, source to stock part of the process flow (Supply Chain Council, 2010). The source processes describe the ordering (or scheduling of deliveries) and receipt of goods and services. The source process embodies the issuance of purchase orders or scheduling deliveries, receiving, validation and storage of goods and accepting the invoice from the supplier (Supply Chain Council, 2010).

Make or production activities are the process of adding value to products through mixing, separating, forming, machining, and chemical processes (Supply Chain Council, 2010). The make processes (Supply Chain Council, 2010) describe the activities associated with the conversion of materials or creation of the content for services.

Deliver or classic supply chain management activities are logistics, mainly warehouse or storing and transportation; the deliver processes (Supply Chain Council, 2010) describe the activities associated with the creation, maintenance and fulfilment of customer orders. The deliver process embodies the receipt, validation and creation of customer orders, scheduling order delivery, pick, pack and shipment and invoicing the customer. Deliver (Supply Chain Council, 2010) means the processes associated with performing customer-facing order management and order fulfilment activities. This is the order to cash stage of the supply chain scheduling (Supply Chain Council, 2010). In the SCOR model, scheduling product deliveries goes against an existing contract or purchase order (Supply Chain Council).

Return includes the processes associated with moving material from a customer back through the supply chain to address defects in product, ordering, or manufacturing, or to perform upkeep activities (Supply Chain Council, 2010).

\section{THEORETICAL ANALYSIS - SCOR AND BUSINESS PROCESS MANAGEMENT}

Using SCOR as the source for standard processes is agreed upon in the dedicated literature by the proponent of the model (Supply Chain Council, 2010), by scientific literature review, by companies' practice to date (Delipinar \& Kocaoglu, 2016), by enterprise resource planning solution providers Oracle, SAP (Trienekens, 2008). Handbooks on business process management (Harmon, 2014) show the evolution of the discipline from the 1980s Porter's value chain framework, business process reengineering to the 2000s and business process management, business process frameworks such as SCOR, CIBIT, eTOM. SCOR is the classical business process framework (Academic Library, 2020). Articles in journals of production management (Wang et al., 2010) argue a strong connection between business process management or reengineering status 2010 and global supply chain management using the SCOR model. Business process engineering is thereby a holistic approach to business activities, performance (Wang et al., 2010), based on the implementation of large-scale information systems in the enterprise context (Chen \& Tsai, 2010). There is a close relationship between business process reengineering, SCOR and business performance (Wang et al., 2010). Some organizations are known to pioneer these concepts: Dell, Walmart, General Motors (Wang et al., 2010). In 2020, Dumas argues about automated process improvement, and notes tasks can be automated if they are determinable. Process improvement refers to execution processes, where decisions are made and processes are improved. Process models are compatible with automation (Dumas, 2019). Poluha (2016) assesses business processes as the quintessence of supply chain management, where SCOR is a classic theoretical framework. Millet et al. (2009) argue an integration between business process management, SCOR and enterprise resource planning. Medini and Bourey (2012) propose using SCOR as a framework for enterprise resource planning. Manuals about business process management (Kirchmer, 2017b) ground business process reference manuals in enterprise resource planning software solutions and Supply Chain Operations Reference 
model. Kirchmer (2017a) refers to supply chain management and SCOR as the standard business process framework, supported by technology. Zgaya and Hammadi in 2016 consider supply chain management information technology and include ERP systems on operational level. ERP systems include purchase management, stock management, transport management, sales administration. Supply chain network planning is a strategic application of SCOR. Business activities, business processes and business process frameworks are an element to be considered in enterprise architecture strategy (Abunadi, 2019). The issues considered are enterprise architecture framework and methodology, strategic practices, business activities, and information systems (Abunadi, 2019). In several views, SCOR enables the standard definition of supply chain management processes and the activities therein. According to the original proponent of SCOR, Supply Chain Council (2010), the standard processes are: order to cash, source to service, plan to make, make to deliver, service. Other supply chain standard bodies confirm these standard processes (International Institute for Procurement and Market Research, 2020). Dumas (2016) notes that business process management techniques in the integrated supply chain to deliver value to customers may be seen as procure to service processes, made up of supplier purchase, lead to quote, quote to order, order to cash, after sale care. Business process management provides performance in the shape of quality, efficiency, agility, flexibility, time, cost (Dumas, 2016). Examples of SCOR implementation (Hafeez et al., 2020) in an oil and gas company in an emerging market show a process flow comprising activities determination of requirements, source determination, vendor selection, ordering process, purchase order monitoring, goods receipt, invoice verification, payment. According to the Project Management Institute (2020), designing the supply chain is a one-time effort, a project, using for example the SCOR Supply Chain Operations Reference model (Breskin, 2002; Stewart, 1997). The model is claimed to span all customer - company interactions across the extended enterprise, that is from customer order to invoice (Breskin, 2002; Stewart, 1997). This is the first integrated supply chain management model (Stewart, 1997). The SCOR model allows to choose from 26 process categories (Stewart, 1997). In the SCOR model (Ward \& Handfield, 2006), supply chain management includes supply chain strategy, performance management, master data management, supply chain design, strategic sourcing, supplier relationship management, demand management, accounts payable. SCOR includes end-to-end processes order to cash and purchase to pay.

\section{EMPIRICAL ANALYSIS - END TO END BUSINESS PROCESSES ACCORDING TO MANAGEMENT CONSULTING COMPANIES}

Hackett (2020a), the leading worldclass benchmark institute for global business services, benchmarks global business processes. In order to obtain best class processes, Hackett recommends process analysis and improvement to worldclass process, followed by the implementation of an Oracle (Hackett, 2020b) or SAP solution. Business process management begins with understanding the practices of world-class firms; continues with configuring client-specific Oracle or SAP solutions that enable best practices; completes the implementation rapidly and efficiently. Hackett (2020b) argue using enterprise resource planning solutions for poor processes works the inefficiencies of existing processes into information technology.

Mc Kinsey (2017a) believe the next operating model of the enterprise is integrated, and comprises journeys, or customer journeys (when making a purchase or receiving services) and internal journeys. Examples of internal journeys are order to cash, purchase to pay, account to report. These end-to-end processes should work together. Mc Kinsey (2017a, 2017b, 2018) furthermore argues for global end-to-end processes, and looks especially at order to cash, purchase to pay as part of an integrated global delivery model. Other similar end-to-end processes are hire to retire in human resources. Other consultants also recognize the value of global business services in integrated processes such as order to cash, procure to pay, hire to retire (Deloitte, 2017). EY, 2017, offer and enterprise end-to-end process governance model that includes: vision to strategy; idea to innovate; business to opportunity; opportunity to order; order to cash; fulfil to schedule; schedule to produce; 
produce to deliver; procure to pay; record to report; hire to retire; supporting areas. Vision to strategy includes the business concept, long-term vision and strategic initiatives. Business to opportunity includes market analysis and marketing. Opportunity to order comprises: sales forecasting and execution, pricing, sales contracts and order generation, availability to promise. Order to cash includes order processing, customer service, credit, accounts receivable, indirect tax. Fulfil to schedule refers to materials, demand, availability to promise production planning, scheduling. Schedule to produce includes detailed scheduling, inbound logistics, receiving, making of goods, managing raw and in-process inventory. Produce to deliver means finished goods storage, warehousing, transportation, customs. Procure to pay includes buying (direct, indirect, goods/services/freight), accounts payable, indirect tax. Record to report is accounting, financial and management reporting and analysis, and direct tax. Hire to retire refers to talent supply and demand, development, total rewards and employee services. Supporting areas are information technology, data, legal, corporate affairs, treasury, corporate audit, reliability. EY (2017) also things managing end-to-end processes is the realm of the global process owner. KPMG $(2018,2020)$ and PWC (2015, 2017, 2020). BCG (2014) envisions the enterprise as consisting of business model and strategy, target operating model, foundation.

According to Everest Global Inc. (2014a, 2014b), the order to cash process comprises activities: billing, order management, dispute and deduction management, aging and collections, accounts receivable. Order to cash process involves sales for quote to order, and activities inquiry, quotation, order management in sales; production for manufacturing activities; order fulfilment for supply chain functioning and activities: scheduling and logistics; billing and invoicing to accounts receivable with activities: billing; dispute resolution and deduction management; aging and collections; accounts receivable. According to Everest Global Inc. (2014a, 2014b), source to pay processes comprise processes source to contract, with activities: spend data management; demand management; strategic sourcing; vendor management; sourcing support and catalogue management and processes purchase to pay: requisition to purchase order; invoice processing; accounts payable and travel and expenses. Procure to pay process includes activities: requisition to purchase order with activities requisition to purchase order: approval workflow, service and material requisition, purchase order, editing and troubleshooting, spot buys; invoice processing: material/ invoice receipt, 3 and 4 way match, approve payments; accounts payable and travel and expense: process payment request, travel and expense claims processing, EDI and P-card processing, month end closing, vendor inquiries, reporting, master data maintenance. The process spans accounting and procurement functions. Manufacturing processes make are also part of supply chain, and shared services do exist to tie manufacturing and logistics. The Hackett (2020c) institute models the order to cash process as comprising activities: sales and quote management; credit and risk management; order processing; invoicing; collections management; dispute management; cash application. The Hackett (2020d) institute models the purchase to pay process as comprising activities: procurement planning and budgeting; selecting and contracting; originating requirement and ordering; tracking, receipting and evaluating; invoice processing; discrepancy management; payment.

\section{EMPIRICAL ANALYSIS - ENTERPRISE RESOURCE PLANNING SOLUTIONS FOR INTEGRATED SUPPLY MANAGEMENT AT SAP AND ORACLE}

Daum (2003) for SAP writes about an integrated enterprise resource planning framework comprising SRM (Supplier Relationship Management), CRM (Customer Relationship Management), PLM (Product Lifecycle Management ) and SCM (Supply Chain Management). In 2020, the mySAP suite (Guru99, 2020) includes solutions SRM (Supplier Relationship Management), CRM (Customer Relationship Management), PLM (Product Lifecycle Management) and SCM (Supply Chain Management). SAP Internet based tutorials (Dresden, 2018; Sabane, 2012; Wholidisapforhire, 2020) show several integrated SAP modules. Several SAP modules: Sales and 
Delivery SD, Production Planning PP, Materials Management MM are integrated for the sales process order to cash, production process and procure process procure to pay to work together (Sabane, 2012). The sales process involves: sales order entry, availability check, materials pick, post good issue, customer invoice, receipt of payment. It interfaces with production process via availability check: run MSP vs MRP; materials pick and order settlement. Production process involves: run MSP vs MRP; convert production proposal; schedule and release; goods issue; completion confirmation; goods receipt; quality inspection; order settlement. Procurement process involves: purchase requisition, purchase order, goods receipt, invoice receipt, payment to vendor. Procurement interfaces with production via purchase requisition and schedule and release; payment to vendor and completion confirmation. In another view, sales order to cash (Sabane, 2012) process involves: pre-sales activity; sales order; delivery; billing; accounts receivable. Procure to pay processes involve: purchase requisition, purchase order, goods receipt, invoice receipt, accounts payable. Sales order and purchase to pay processes and sales order and produce processes interface via logistics and the following process flow: in inventory; plant or warehouse; inventory postings. In inventory connects processes sales order, via availability check and if not the issuance of purchase requisition; the same logistics activity connects sales order via availability check with planned order. Plant or warehouse links activities goods receipt, with goods from purchase order, and delivery, with goods to delivery. The logistics activity links with activities production order, via the issuing of goods to production order; with activities completion confirmation, goods from production order; with activities delivery, via goods issued to delivery. General ledger accounts group accounts receivable, accounts payable, inventory. IBM Global Services (2008) integrates planned requirements in SAP Production Planning, SAP Material Management, SAP Sales and Distribution, SAP Financial Accounting FI. SAP Production Planning to MRP and planned order, production order, production completed and order settlement in SAP Controlling. In SAP Materials Management, requirement on component level, purchase order, goods receipt, invoice verification, accounts payable in SAP FI. In SAP SD, customer orders trigger shipping, invoicing, accounts receivable in FI. The integration refers to SAP modules MM, PP and SD linking suppliers and customers and being linked to SAP FICO. In another version (Dresdner, 2018), mySAP comprises several SAP modules: SAP FI, SAP MM, SAP Logistics, SAP PP, SAP SD and their integration. For example, in one view (Dresdner, 2018), SAP modules Sales Distribution SD, Materials Management MM and Logistics Execution LE are linked. MM ordering involves the vendor and the following document flow: purchase order processing, inbound delivery, inbound shipment, good receipt, invoice verification. Sales and distribution SD order processing involve: sales order processing, outbound delivery, goods issue, outbound shipment, customer, billing. The Logistics Execution LE module links vendor with inbound shipment, goods receipt, logistics execution, goods issue, outbound shipment, customer. A similar view (Wholidisapforhire, 2020) looks at SAP organization structure by functional module, includes SAP SD, SAP MM, SAP FI and their integration. In this logic, activities start with SAP SD in the following order: sales organization, distribution channel, division, sales office, sales group; sales organization also works with credit control area (Wholidisapforhire, 2020). In SAP FI, company code area work with sales organization, controlling area, and lead to credit control area and valuation area (Wholidisapforhire, 2020). In Material Management, purchasing organization works with company code, purchasing group, plant; plant works with valuation area, distribution channel, storage location, MRP, shipping point and therefrom loading point (Wholidisapforhire, 2020). Scientific manuals write about the integration of SAP modules FI, SD and MM (Okungbowa, 2015). In relation to supply chain management, end-to-end processes order to cash, production and procure to pay stand out.

SAP SD interfaces with SAP FI typically manages the order to cash processes (ToughNickel, 2020). Order to cash accounting involves both finance and sales and distribution modules. It starts with customer inquiry and goes on with quote in the source to order process. The customer is responsible for this stage, where the quote refers to the item and the order for the quantity needed. Follows order to cash: an internal order; inventory from warehouse to customer via the goods delivered note; 
the billing process involves finance and documents such as invoice, debit memo or credit memo, cash collection, credit management. SAP Tutorials (2020b) involve the following process: raising sales order; checking availability; outbound delivery; transportation; goods pickup; issuing goods; billing; processing payment. In the view of SAP Community Wiki (2014), the main areas covered by SD module are: pre-sales activities, including inquiry and quotation creation; sales order processing, including sales order creation; shipping, including outbound delivery document creation; billing, including billing document and invoice creation. According to SAP Online Guides (2020), SAP SD involves the following process chain: raising sales order; checking availability; outbound delivery; transportation; goods pick up; issuing goods; billing; processing payment. The Sales and Distribution module in SAP interfaces with Sales Information System, Material Management and Production Planning (SAP Online Training, 2020). Presales activity includes customer contract; contact, inquiry and quotation; scheduling agreement (SAP Online Training, 2020). This is the source to order process. Follow sales order, inventory sourcing, delivery transportation, billing and payment accounting (SAP Online Training, 2020). Delivery transportation includes delivery, goods issue, transfer order, shipment (SAP Online Training, 2020). Billing means invoice. Payment accounting includes account receivables and material stock account (SAP Online Training, 2020).

SAP Tutorials (2020a) show SAP MM processes as comprising the following activities: determination of requirement; requisition; purchase order; goods receipt/ invoice received; invoice verification/ vendor payment. SAP MM (Jain, 2009) involves the following process chain: requisitions, purchase orders, goods receipts, accounts payable, inventory management, bill of material, master raw materials, finished goods. Purchasing (Jain, 2009) issues orders suppliers who engage in receiving activities, raw material storage, transformation processes, in process storage, finish goods storage, distribution to customer. Procure to pay process (Gaines, 2016) involve the following: purchase requisition, vendor selection, purchase order, notify vendor, vendor shipment, goods receipt, invoice receipt, payment to vendor. Procurement environment (Cain, 2018) includes requirement determination, source determination, vendor selection, order processing, order followup, goods receipt or inventory management, invoice verification. SAP Tutorials (SAP Tutorials, 2020a) hold not only purchase to pay, but the full source to pay process is valid. The SAP MM process holds the following activities: purchase requisition, request for quotation, vendor evaluation, purchase order, goods receipt, invoice verification. SAP MM (Gollapini, 2019) holds the following process stages: requirement determination; source determination; vendor selection; purchase order processing; purchase order monitoring; goods receipt; invoice processing; payment processing. In another view (Wikimedia Commons, 2020) the purchase to pay process is as follows: supplier management; request for quotation; contracts; catalogues; procurement; budgets planning; budgets; receiving; asset management; invoices; reporting.

Oracle $(2013 ; 2016)$ solutions for integrated supply chain management are based on the SCOR model. The solutions refer to stages: design, enable, plan, source, make, deliver (Oracle, 2016). The design stage refers to product design activities (Oracle, 2016). The enabling phase contains purchasing analysis, sourcing agreements, contract management (Oracle, 2016). The plan phase refers to collaborative planning, supply commits, inventory replenishment (Oracle, 2016). The source phase refers to purchasing execution; shipment tracking; payment and reconciliation (Oracle, 2016). The source phase includes activities of iprocurement, sourcing, isupplier portal, purchasing (Oracle, 2016). The make phase refers to outsourced manufacturing, quality (Oracle, 2016). The activities at the make stage are discrete manufacturing, shop floor management, manufacturing scheduling, flow manufacturing (Oracle, 2016). The plan stage refers to collaborative planning, supply commitments, inventory replenishment (Oracle, 2016). Activities at the plan stage include demand planning, supply chain planning, inventory optimization, collaborative planning (Oracle, 2016). The deliver stage refers to logistics, order promising, receivables (Oracle, 2016). The deliver stage includes activities like global order promising, trade/ order management, warehouse management, transportation (Oracle, 2016). The return stage contains activities isupport, telecom 
service, field service, depot repair, service contracts (Oracle, 2016). In demand driven order management, the workflow driven process involves several departments: planning, purchasing, manufacturing, finance, warehouse management, transportation management (Oracle, 2016). An integrated process approach begins with capturing sales quotes, configuring, pricing, checking availability, scheduling, planning shipment, shipping and tracking, invoicing and payment (Oracle, 2016). As a major achievement, the Oracle system enables cross-functional process optimization (Oracle, 2016). The goal of this integrated process approach is matching supply and demand and process optimization (Oracle, 2006). The solutions enable end to end business flows: procure to pay; forecast to plan; plan to manufacture; order to cash; service (Oracle, 2013, 2016).

Process management manuals (Kirchmer, 2017a, 2017b) mention SCOR and ARIS as the generally accepted models for business process management. At Software AG (2016), ARIS is a solution for business process management that may be used together with SCOR. The supply chain management standard setter APICS and Software AG (2016), work as a business process analysis framework to get insight into the dynamics of companies' business processes and supply chain management systems. They unify software, business process management and supply chain management.

\section{EMPIRICAL DATA ANALYSIS - THE MOST IMPORTANT GLOBAL BUSINESS SERVICE PROVIDERS WORLDWIDE AND IN ROMANIAN SUBSIDIARIES}

A report by the Ministry of Economy, Energy and Business Environment (2020) shows a large number of information technology and outsourcing companies located in Romania. The report shows a total of over 100000 employees in business service outsourcing, therein over 80000 located in Bucharest, 15000 located in Cluj, and 11000 located in Timisoara. For instance, in Bucharest, key market players are: Oracle, IBM, Microsoft, Google, Dell, Wipro, Endava, Bosch, Adobe, Deutsche Bank, Hewlett Packard, Huawei, Orange, Deutsche Bank, Hewlett Packard, Bosch, Adobe, Orange, Arvato, WNS, Societe Generale, SAP, Conectys, Global Remote Services, CapGemini, Sykes, Unicredit, Genpact, OMV, Stefanini, Bitdefender, Metrosystems, Siemens, Comdata Group, CGS, PWC, Hewlett Packard, Gameloft, Hella, EY, KPMG, Deloitte, Accenture, Siveco, Electronic Arts, Luxoft, Softvision, Hella, Gameloft, Telus, SoftIntelligence, Atos, Ericsson, Pentalog. Similar market play lists are found in Cluj, Timisoara, Iasi, Brasov. The report names some 200 companies playing on the Romanian market. Of these players, some are the most important business process outsourcing providers in the world. These may be a useful benchmark. Previous research on behalf of the authors (Petrisor \& Cozmiuc, 2016) shows a large number of Romanian subsidiaries providing shared services and the advantages of process expertise in such units.

According to a major consultant in business process outsourcing, the Everest Group, order to cash and source to pay processes span the supply chain from customers to suppliers. Everest Group Research (2014) shows order to cash processes are amongst the most popular for business process outsourcing providers on global scale. Names with offices in Romania include information technology experts that are also business process outsourcing companies: Accenture, Genpact, Wipro, CapGemini, Infosys, HCL, Tata Consultancy Services and global manufacturers: Dell, Hewlett Packard, IBM. The Ministry of Economy, Energy and Business Environment (2020) includes other names such as Huawei, Pfizer, Bosch, Continental, Hella. Order to cash services and procure to pay are the most popular end-to-end processes spanning customers and vendors. The order to cash process spans various activities and functions, which functions include the sales function for quote to order, production (manufacturing), supply chain, billing and invoicing. Accenture (2016) is a global business outsourcing services provider of global scale with offices in Romania. In Romania, Accenture provides order to cash services noted as such (Accenture, 2020a) and order to cash organization consulting (LinkedIn, 2020a). Prnewswire (2015) names Genpact a global leader in order to cash and account to report services. A bundle of order to cash activities are organized by Genpact (2020a) in Romania. Wipro (2020a) and SAP develop together global 
solutions for various industries. In Romania, Wipro (2020b) hired for order to cash with various foreign language expectations. On global scale, CapGemini (2013) offers order to cash processes. Evidence such jobs are hosted in Romania is shown on LinkedIn (2020d), where CapGemini offers consultancy services in Bucharest. Infosys is another global technology and business process outsourcing services provider headquartered in Bucharest Romania (Profit Romania, 2019). On global scale, Infosys (2020a) provides quote to cash services, including order to cash. Another large global technology and business process outsourcing services provider is HCL. Whereas global evidence clearly shows the provision of order to cash services (HCL, 2015), the Romanian subsidiary in Iasi showcases a bundle of finance jobs with local languages and no further details. Tata Consultancy Services (2020) provides services for order to cash and is recognized as leader by reference business process outsourcing analyst Everest Group. Tata Consultancy is known as one of the reference business process organizations located in Brasov Romania. On global scale, manufacturers Dell, Hewlett Packard, IBM, Bosch are amongst the largest and most important business process outsourcing providers. On global scale, Dell (2013) provides order to cash services. Dell (2020a) integrates customers' procurement processes at all stages, including quotations. In Romania, Dell (2020b) hires order management specialists with foreign language expectations. Dell Perot Systems Romania (2010) is a large global business process outsourcing location that includes customer service support. At Perot Systems (Ejobs, 2020), Dell advertizes a large series of jobs many of which are across order to cash processes. These include order management and collection specialist. Processes may be quote to cash rather than lead to cash. On worldwide level, Hewlett Packard's (2005) organizes order to cash services. Part of these services are performed at a local Romanian based business process outsourcing center (Hewlett Packard, 2020). At IBM Global Business Services (2005), the Global Business Services include invoice to cash. IBM Romania (2020a) shows evidence of the full order to cash process located here. At Huawei (Huang, 2019), financial management is executed through end-to-end business processes one of which is order to pay. In Romania, Huawei has two global business centers, evidence show jobs integrated order management, inventory, purchasing and financial management (Huawei, 2008). Pfizer shared services are amongst the largest shared service centers worldwide. Pfizer is rated one of the top employers in the business services sector in Romania (Consilium Europa, 2017). A large business process outsourcing center at Bosch (2020c, 2020e) hires order to cash personnel in Romania and across the world. Continental Business Services (Bestjobs, 2020) advertizes accounts receivable related jobs. Disparate accounts payable are also serviced at Hella (2020).

Everest Group Research (2014) shows order to cash processes are amongst the most popular for business process outsourcing providers on global scale. Other market reports show that, on global scale, procurement outsourcing service providers include information technology experts: Accenture, IBM, Procurian, GEP, Infosys, Xchanging, Proxima, CapGemini, Genpact (HfS, 2014). Procure to pay are the traditional realm of business process outsourcing services (CapGemini, 2020). Inspired by Everest Group, names with offices in Romania include technology and business process outsourcing companies: Accenture, Genpact, Wipro, CapGemini, Infosys, HCL, Tata Consultancy Services and global manufacturers: Dell, Hewlett Packard, IBM, Bosch, Continental, Hella. The Romanian Ministry of Economy (2020) includes other names such as Huawei, Pfizer, Bosch, Continental, Hella. Accenture is a global leader in procure to pay services (Accenture, 2015). In Romania, Accenture (2020b) advertizes procurement jobs about purchase requisitions, purchase orders, logistics, invoices, contracts. Genpact (2020b) is also a leader in source to pay process. Genpact's process management is reputed to bring agility to supply chain management (Supply Chain Digital, 2020). Procure to pay processes have been reported in Romania since 2010 (Genpact, 2010). Wordpress (2020) claims Wipro is world leader in procure to pay process provision. In Romania, Wipro (2020a) advertizes accounts payable jobs. CapGemini (2020) advertizes about holistic procure to pay processes worldwide. In Romania, CapGemini (2011) procurement services have local subsidiary advertizing local jobs. Infosys (2020b) advertizes global 
procure to pay services on worldwide level. Infosys Romania has a large local center in Romania (Profit Romania, 2019). At HCL, Procure to Pay is part of excellent supply chain solutions (HCL, 2018). No procure to pay services were noted in Romania. Tata Consultancy Services (2017) advertizes procure to pay processes worldwide. In Romania, LinkedIn (2020c) information shows procure to pay team leader jobs at Tata Romania. At Dell (2013), procure to pay services are a traditional business process outsourcing service. Dell (2020c) shows evidence of global procurement and procurement integration. No evidence shows such local service provision in Romania. Hewlett Packard is a worldwide tier 1 provider for business process outsourcing services. Hewlett Packard also shows leadership of large Romanian organization in procurement services for categories (LinkedIn, 2020b), a service part of the quote to pay process integrally. At IBM (2020b), Global Procurement is about the source to pay process. Huawei advertizes jobs tied to one of the activities in source to pay, category management (LinkedIn, 2020a). A large Romanian business process outsourcing Bosch subsidiary (2020d) hosts purchase to pay activities. Continental Business Services (2020a) provides purchasing and accounts payable services in a global process framework, SPIRIT, recently adopted.

Some companies in Romania support customers and supply chain management via further operational processes. A logistics hub and supply chain coordination center is held by Pfizer in Romania (Business Review, 2017) responsible of planning inventory and supply chain related activities. At Hewlett Packard (2020) with a large subsidiary in Romania, sales support involves sales forecasting and reporting; sales forecasting and reporting; product pricing support; partner compensation and rewards administration. In Romania, the largest business process outsourcing company worldwide, Bosch, provides business services to support manufacturing execution (Bosch, 2020a). Bosch provides complex process support for advanced manufacturing issues including Industry 4.0 (Bosch, 2020b). At Continental, Continental Engineering Services (Continental, 2020b) provides highly specialized engineering support services for manufacturing execution amongst others and is represented in Romania.

\section{CONCLUSIONS}

Shared services take over disparate activities from home locations and execute them exactly as are. Global business services are more advanced than shared services, and add process expertise and information technology expertise. Consultants such as Hackett advise global business services begin with the process model, be it theoretical reference or worldclass benchmark, and continue with information technology design, for instance in SAP or Oracle systems. A large body and wide variety of sources consent about process definition, where examples of end-to-end processes are lead to order, order to cash, procure to pay. These sources are supply chain management certification providers, business management theory, management consultants, enterprise resource planning solution providers Oracle and SAP, the most important business process outsourcing companies worldwide. These sources indicate the value add of process modelling theory and worldclass benchmarks to business services. This requires active and proactive process and information technology expertise in an integrated organization. The alternative was the passive take-over of business processes in organizational silos. The value add of the former approach stands out. In Romania, over 200 companies that provide business services have been identified in market research and benefit from process and information technology expertise. The study shows that business process expertise, information technology expertise and global service provision in a dedicated center are complimentary and implemented as such by leading organizations. 


\section{REFERENCES}

Abunadi, I. (2019). Enterprise Architecture Best Practices in Large Corporations. Information (Switzerland), 10 (10), 293.

Academic Library (2020). Business Process Frameworks?. Retrieved on August 15, 2020, from https://ebrary.net/18126/management/business_process_frameworks

Accenture (2015). Procure-to-Pay. Retrieved on August 20, 2020, from https://www.accenture.com/_acnmedia/Accenture/ConversionAssets/DotCom/Documents/Global/PDF/Dualpub_7/Accenture-Procure-To-Pay-Roadmapnfographic.pdf

Accenture (2016). Connected Order to Cash: Powered by Digital and Analytics. Retrieved on August 20, 2020, from https://www.accenture.com/t00010101T000000_w_/gben/_acnmedia/PDF-33/Accenture-Connected-Order-Cash-POV.pdf

Accenture (2020a). Credit \& Collection Global Reporting Analyst. Retrieved on August 20, 2020, from $\quad$ https://www.glassdoor.com/Job/romania-credit-collection-jobsSRCH_IL.0,7_IN203_KO8,25.htm

Accenture (2020b). Reducing costs through a streamlined procure to pay approach. Retrieved on August 20, 2020, from https:/www.accenture.com/us-en/service-reducing-costs-throughstreamlined-procure-to-pay-approach

AIMS (2020). What is Supply Chain Management?. Retrieved on August 22, 2020, from https://aims.education/study-online/what-is-supply-chain-management-definition/

The Association of Chartered Certified Accountants. 2012. Finance transformation: experts insights on shared services and outsourcing. Retrieved on September 01, 2020, from www.accaglobal.com > acca > global > PDF-technical

Association for Supply Chain Management (2019). xCOR - a Value Chain Framework Ontology. Retrieved on June 05, 2020, from https://www.slideshare.net/lswt/xcor-a-value-chainframework-ontology

Association for Supply Chain Management (2020). Certified in Production and Inventory Management (CPIM). Retrieved on June 05, 2020, from https://www.ascm.org/learningdevelopment/certifications credentials/cpim/

BCG. (2014). The operating model ecosystem. Retrieved on August 15, 2020, from https://ashridgeonoperatingmodels.com/2014/07/28/bcgs-approach-to-operating-models/

Bestjobs. (2020). Retrieved on August 15, 2020, from https://www.bestjobs.eu/en/jobs/continental

Borges, M. A. V. (2015). An evaluation of supply chain management in a global perspective. Independent Journal of Management \& Production, 6 (1).

Bosch (2020a). Bosch Service Solutions Timişoara. Retrieved on August 09, 2020, from https://www.bosch.ro/compania-noastra/bosch-in-romania/timisoara-bosch-servicesolutions/

Bosch (2020b). IT Operations Engineer - Database Specialist for IOT/Industry 4.0. Retrieved on August 09, 2020, from https://www.hipo.ro/locuri-de-munca/locuri_de_munca/145362/BoschService-Solutions-SRL/IT-Operations-Engineer-\%E2\%80\%93-Database-Specialist-forIOT/Industry-4.0

Bosch (2020c). Process Partner - Order to Cash (O2C). Retrieved on August 09, 2020, from https://jobs.smartrecruiters.com/BoschGroup/743999697986397-process-partner-order-to-casho2c-

Bosch (2020d). Procure to pay. Retrieved on October 09, 2020, from https://jobs.smartrecruiters.com/BoschGroup/743999717379804-praktikum-im-bereichprocess-excellence-procure-to-pay

Bosch (2020e). SAP O2C Consultant/SAP O2C_CI. Retrieved on August 09, 2020, from https://www.glassdoor.com/Job/suzhou-jiangsu-sap-o2c-consultant-sap- 
o2c\%E9\%A1\%BE\%E9\%97\%AE-ci-jobs-

SRCH_IL.0,14_IC2677883_KO15,46.htm?src=GD_JOB_AD\&rdserp=true\&srs=EI_JOBS\&jl $=3649577910 \& a 0=874694 \& s=21 \&$ guid $=00000174$ caebb1899c1fa386d9c5faa2\&pos $=102 \& \mathrm{t}=\mathrm{E}$ SR\&ei=4293\&extid=2\&exst=EO\&ist=L\&ast=EOL\&vt=w\&slr=true\&cs=1_65443d5b\&cb=16 01132278528\&jobListingId $=3649577910$ bestjobs

Breskin, I. (2002). Modelling a supply chain. PM Network, 16(4), 44-48.

Business Review (2017). Pfizer announces opening of regional logistics service in Romania. Retrieved on October 01, 2020, from https://business-review.eu/news/pfizer-announcesopening-of-regional-logistics-service-in-romania-135793

Cain, P. (2018). SAP Materials Management (MM). Retrieved on September 05, 2020, from https://slideplayer.com/slide/12701168/

CapGemini (2011). QA Engineer. Retrieved on September 18, 2020, from https://www.ejobs.ro/user/locuri-de-munca/qa-engineer/469458

CapGemini (2013). Streamlining the Order-to-Cash process. Retrieved on September 19, 2020, from https://www.capgemini.com/cn-zh/wp-content/uploads/sites/12/2017/08/streamliningthe-order-to-cash-process.pdf

CapGemini (2020). Procure to Pay (P2P). Retrieved on September 18, 2020, from https://www.capgemini.com/service/business-services/transform-your-financeoperations/procure-to-pay/

Chartered Institute of Logistics and Supply Chain Management (2020). The Chartered Institute of Logistics and Supply Chain Management. Retrieved on June 01, 2020, from https://www.cilscmglobal.org/

Chartered Institute of Procurement and Supply (2020). Supply Chain Management. Retrieved on June 01, 2020, from https://www.cips.org/knowledge/procurement-topics-and-skills/supplychain-management/

Chartered Institute of Supply Chain Management (2020). Global Supply Chain Management Certifications. Retrieved on June 01, 2020, from https://ciscmglobal.us/global-supply-chainmanagement-certifications/

Chen, C., K. \& Tsai, C., H. (2010). Developing a process re-engineering-oriented organizational change exploratory simulation system (PROCESS), International Journal of Production Research, 46 (16).

Consilium Europa (2017). Bucharest. Smart Agency in Vivid European City. Retrieved on October 01, 2020, from https://www.consilium.europa.eu/media/21817/bucharest-emaoffer.pdf

Continental (2020a). Operations Lead - GBS TSR. Retrieved on October 01, 2020, from https://www.bestjobs.eu/en/job/operations-lead-gbs-tsr-2

Continental (2020b). Service Portfolio. Retrieved on October 01, 2020, from https://contiengineering.com/service-portfolio/

Council of Supply Chain Management Professionals (2020). CSCMP Supply Chain Management Definitions and Glossary. Retrieved on June 01, 2020, from https://cscmp.org/CSCMP/Educate/SCM_Definitions_and_Glossary_of_Terms/CSCMP/Educa te/SCM_Definitions_and_Glossary_of_Terms.aspx?hkey=60879588-f65f-4ab5-8c4b6878815ef921\#: :text=CSCMP\%E2\%80\%99s\%20Definition\%20of\%20Supply\%20Chain\%20 Management.\%20Supply\%20chain,and\%20procurement,\%20conversion,\%20and\%20all\%20lo gistics\%20management\%20activities

Creazza, A., Dallari, F., \& Melacini, M. (2010). Evaluating logistic network configurations for a global supply chain. Supply Chain Management, 15(2).

Dag, N. \& Hulthen, H. (2012). Supply chain management integration: A critical analysis. Benchmarking, 19(4/5).

Daum, J. (2003). Intangible assets and value creation. John Wiley and Sons 
Delipinar, G. E. \& Kocaoglu, B. (2016). Using SCOR model to gain competitive advantage: A Literature review. Procedia - Social and Behavioral Sciences, 229, 398 - 406.

Dell (2013). Transform your back-office finance and accounting processes to improve business results. Retrieved on September 20, 2020, from https://i.dell.com/sites/doccontent/sharedcontent/data-sheets/it/Documents/dell_finance_and_accounting_bpo_services_it.pdf

Dell (2020a). Dell Technologies. Retrieved on September 20, 2020, from https://www.delltechnologies.com/ro-ro/video-collateral/procurement-integration.htm

Dell (2020b). Order Management Specialist with Italian. Retrieved on September 20, 2020, from https://jobs.dell.com/job/bucharest/order-management-specialist-with-italian/375/17240413

Dell (2020c). Transform the way you purchase IT. Retrieved on September 23, 2020, from https://www.delltechnologies.com/ro-ro/premier-solutions/index.htm\#accordion0

Dell Perot Systems Romania (2010). Delivering value-added services to Global Customers. $\begin{array}{lllll}\text { Retrieved on } & \text { September } & 20, & \text { from }\end{array}$ https://www.amcham.ro/download?file=mediaPool/Prezentare_Dell\%20Perot\%20Systems \%20Romania_11\%20feb_02161424.pdf

Deloitte (2017). The value of Global Business Services. Retrieved on August 10, 2020, from https://www2.deloitte.com/content/dam/Deloitte/us/Documents/process-and-operations/ussdt-ask-the-pro-chris-ahn.pdf

Demand Driven Institute (2020a). Demand Driven Planner. Retrieved on August 11, 2020, from https://www.demanddriveninstitute.com/demand-driven-planner-ddp

Demand Driven Institute (2020b). The Association for Supply Chain Management launches to focus on transformation and innovation. Retrieved on August 11, 2020, from https://www.supplychaindigital.com/supply-chain/association-supply-chain-managementlaunches-focus-transformation-and-innovation

Dresdner, H. (2018). SAP SD Overview. Retrieved on September 11, 2020, from https://slideplayer.com/slide/14150652/

Drucker, P.F. (2017). The Age of Discontinuity: Guidelines for Our Changing Society. Routledge

Dumas, M. (2016). BPM Techniques and Tools. Retrieved on August 15, 2020, from https://www.slideshare.net/MarlonDumas/bpm-techniques-and-tools-a-quick-tour-of-the-bpmlifecycle

Dumas, M. (2019). Metaheuristic Optimization for Automated Business Process Discovery. Retrieved on August 15, 2020, from https://www.slideshare.net/MarlonDumas/metaheuristicoptimization-for-automated-business-process-discovery

Dumas, M. (2020). Automated Process Improvement: Status, Challenges, and Perspectives. Retrieved on August 15, 2020, from https://www.slideshare.net/MarlonDumas/automatedprocess-improvement-status-challenges-and-perspectives

Ejobs (2020). S.C. PEROT SYSTEMS ROMANIA S.R.L.. Retrieved on August 15, 2020, from https://www.ejobs.ro/locuridemunca/S.C.\%20Perot\%20Systems\%20Romania\%20S.R.L.

Everest Global Inc. (2014a). Order to Cash (O2C) BPO - Service Provider Landscape with PEAK Matrix Assessment 2014. Retrieved on August 25, 2020, from http://www2.everestgrp.com/Files/previews/EGR-2014-1-R-1344-preview.pdf

Everest Global Inc. (2014p). Procure to pay (P2P) Outsourcing - Service Provider Landscape with PEAK Matrix Assessment 2014. Retrieved on August 25, 2020, from http://www2.everestgrp.com/Files/previews/EGR-2014-1-R-1253-preview.pdf

EY (2017). Is your business equipped for successful transformation?. Retrieved on August 05, 2020, from https://assets.ey.com/content/dam/ey-sites/ey-com/en_gl/topics/advisory/ey-isyour-business-equipped-for-successful-transformation.pdf

EY (2020). Global Business Services. Retrieved on August 05, 2020, from https://www.ey.com/en_gl/consulting/global-business-services

Gaines, A. (2016). Procure to pay process. Retrieved on September 05, 2020, from https://slideplayer.com/slide/8295917/ 
Genpact (2010). Genpact Expands its Presence in Romania. Retrieved on September 15, 2020, from https://www.genpact.com/docs/pr/pr_genpact_romania_expansion_032510-(1)

Genpact (2020a). Order to Cash Team Leader. Retrieved on September 15, 2020, from https://www.bestjobs.eu/en/job/order-to-cash-team-leader-1727351

Genpact (2020b). Source to pay. Grow profit, mitigate risk, and boost innovation with strategic Procurement. Retrieved on September 15, 2020, from https://www.genpact.com/procurementsupply-chain/source-to-pay

Gollapini, O. (2019). SAP MM - Purchasing Flow in a Nutshell. Retrieved on September 05, 2020, from https://blogs.sap.com/2019/04/10/sap-mm-purchasing-flow-in-a-nutshell/

Guru99 (2020). What is mySAP?. Retrieved on August 14, 2020, from https://www.guru99.com/what-is-mysap.html

Hackett (2020a). Business benchmarking. Retrieved on August 08, 2020, from https://www.thehackettgroup.com/business-benchmarking/

Hackett (2020b). Getting the Most Value from Your Oracle Implementation. Retrieved on August 08, 2020, from https://www.thehackettgroup.com/oracle-implementation/

Hackett (2020c). Working Capital Management: Accounts Payable Solutions. Retrieved on August 09, 2020, from https://www.thehackettgroup.com/working-capitalmanagement/accounts-payable/

Hackett (2020d). Working Capital Management: Accounts Receivable Solutions. Retrieved on August 10, 2020, from https://www.thehackettgroup.com/working-capitalmanagement/accounts-receivable/

Hafeez, I., Khalid, R. and Mir, S. (2020). SCOR Implementation in Oil and Gas Company from an Emerging Market. In: Supply Chain and Logistics Management: Concepts, Methodologies, Tools, and Applications, IGI Global, Doi: 10.4018/978-1-7998-0945-6.ch041.

Harmon, P. (2014). The Scope and Evolution of Business Process Management. Handbook on Business Process Management. Springer

HCL Technologies (2015). Power Your Order to Cash Cycle. Retrieved on September 18, 2020, from https://www.slideshare.net/hcl/power-your-order-to-cash-cycle

HCL Technologies (2018). Delivering a smarter supply chain with excellence | HCL. Retrieved on September 18, 2020, from www.hcltech.com > files > brochure > files > 2018/02/12

HCL Technologies (2020). Finance Commercial Manager with Spanish. Retrieved on September 18, 2020, from https://www.careerjet.ro/jobad/rof82295ee4b9a3e5efff7721286190667

Hfs (2013). HfS Blueprint Report. Procurement Outsourcing Services Excerpt for Accenture.

Retrieved on September 18, 2020, from https://www.accenture.com/roen/ /media/Accenture/Conversion-

Assets/DotCom/Documents/Global/PDF/Operations_1/Accenture-HfS-Blueprint-ReportProcurement-Outsourcing.pdf

Hella (2020). Accounts Payable Specialist. Retrieved on August 18, 2020, from https://www.bestjobs.eu/en/job/accounts-payable-specialist-30

Hewlett Packard (2005). HP Business Process Outsourcing for discrete manufacturing companies. Retrieved on September 20, 2020, from ftp.hp.com > pub > services > outsourcing > info BPO

Hewlett Packard (2020). About Hewlett Packard Enterprise. Retrieved on October 01, 2020, from http://dev.absl.ro/partner/hewlett-packard-enterprise/

Huang, W. (2019). Built on value: The Huawei philosophy of finance management, Singapore: Palgrave Macmillan.

Huawei (2008). SSC GL Accountant. Retrieved on September 24, 2020, from https://www.hipo.ro/locuri-de-munca/locuri_de_munca/7236/Huawei-Enterprise-RomaniaGSC/SSC-GL-Accountant

IBM (2020a). Customer support. Retrieved on September 23, 2020, from https://www.ibm.com/planetwide/ro/ 
IBM (2020b). IBM Global Procurement. Retrieved on September 23, 2020, from https://www.ibm.com/procurement/home

IBM Global Services (2008). ERP/ SAP Overview. Retrieved on September 25, 2020, from https://slideplayer.com/slide/10946446/

IBM Global Business Services (2005). Finance shared services and outsourcing. Magical, mythical or mundane?. Retrieved on September 25, 2020, from ftp.software.ibm.com > post_events > services_summit

Infosys (2020a). Order-to-Cash Solutions. Retrieved on September 16, 2020, from https://www.infosysbpm.com/offerings/functions/finance-accounting/serviceofferings/Pages/FA-quote-to-cash.aspx

Infosys (2020b). Procure-to-Pay Outsourcing Services. Retrieved on September 16, 2020, from https://www.infosysbpm.com/offerings/functions/finance-accounting/serviceofferings/Pages/procure-to-pay.aspx

International Institute for Procurement and Market Research (2020). Certified Supply Chain Specialist (CSCS). Retrieved on June 01, 2020, from https://iipmr.com/education/cscs.html

International Society of Supply Chain Professionals (2020). A Blackbelt approach to supply chain management. Retrieved on June 02, 2020, from https://isssp.org/resources/a-black-beltapproach-to-supply-chain-management-realizing-six-sigma-payoff-in-the-office-environment/

International Supply Chain Education Alliance (2020). About ISCEA. Retrieved on June 02, 2020, from https://www.iscea.org/about-iscea

Institute for Supply Chain Management (2020). The Most Recognized Supply Management Certification. Retrieved on June 02, 2020, from https://www.ismworld.org/certification-andtraining/certification/cpsm/

Jain, R. (2009). SAP MM. Retrieved on June 05, 2020, from https://www.slideshare.net/501249296/sap-mm

Kagermann, H., Wahlster, W., \& Helbig, J. (2013). Recommendations for implementing the strategic initiative Industrie 4.0: Final report of the Industrie 4.0 Working Group. Retrieved on August 16, 2020, from http://www.acatech.de/fileadmin/user_upload/Baumstruktur_nach_Website/Acatech/root/de/M aterial_fuer_Sonderseiten/Industrie_4.0/Final_report_Industrie_4.0_accessible.pdf

Kirchmer, M. (2017a). Successful innovation through business process management. Retrieved on August 18, 2020, from https://insights.btoes.com/business-transformation-operationalexcellence/successful-innovation-through-business-process-management

Kirchmer, M. (2017b). Reference Models: Accelerators and More. High Performance Through Business Process Management. Springer

KPMG (2016). Governance in global business services. Retrieved on August 11, 2020, from https://assets.kpmg/content/dam/kpmg/xx/pdf/2016/09/gbs-pov-governance.pdf

KPMG (2018). Source to pay: delivering value beyond savings. Retrieved on August 11, 2020, from https://assets.kpmg/content/dam/kpmg/us/pdf/2016/12/kpmg-ivalua-s2p-delivering-valuebeyond-savings.pdf

KPMG (2020). KPMG Target Operating Model. Retrieved on August 11, 2020, from https://home.kpmg/xx/en/home/insights/2019/10/kpmg-target-operatingmodel.html\#: :text=To\%20overcome\%20this\%20weakness\%2C\%20the,Technology\%2C\%20 Performance\%20Insights\%20and\%20Governance

LinkedIn (2020a). Category Manager Indirect Procurement Western Europe. Retrieved on September 11, 2020, from https://www.linkedin.com/in/serban-stanoiu5b3aba10/?originalSubdomain=ro

LinkedIn (2020b). Global Procurement, HP Inc.. Retrieved on September 11, 2020, from https://ro.linkedin.com/in/daniel-lica-

38933230?challengeId=AQFnOBc5aab0oQAAAXTQszUL8ZcucSxOwCpUmbHxLuRunb0W 
Xg_gHkUybqpuTybxxB-7xxVrQiSRdi5s7qeTajRyBMFTKDJq8w\&submissionId=ab30b37082b5-3816-256a-debf1c996467

LinkedIn (2020c). P2P Team Lead at Tata Consultancy Services. Retrieved on September 11, 2020, from https://ro.linkedin.com/in/alexandra-cristescu82664722?challengeId=AQHJo0fViBIAEwAAAXTQddE6ufnoC59csLoB4zfDf6vVz89Yb1ur MaRv-ZYxuPhdx9ND-fM_ZMEK0X5qexpSD4jInsesoKciIw\&submissionId=736b01b5-d9b13816-4d88-741179b6cd60

LinkedIn (2020d). Senior Project Manager / Managing Consultant. Retrieved on September 11, 2020, from https://ro.linkedin.com/in/alexandru-guta-68583513?challengeId=AQGahwtVFmM0AAAAXTF5p40XbjUMAxIr3xvdtLOdnzeS5MF3MBFxFNEHFvMNS0DPUG8sr0wt3vsp vYBcLwZtA9JPXh_VXEUWw\&submissionId=858e9626-ba10-3816-b713-3e83fbd37a72

Kumar, C. G. \& Nambirijan, T. (2013). Supply chain management components, supply chain performance and organizational performance: A critical review and development of conceptual model. International Journal of Global Business Management and Research, 2(1)

Mc Kinsey (2017a). The next-generation operating model for the digital world. Retrieved on August 15, 2020, from https://www.mckinsey.com/business-functions/mckinsey-digital/ourinsights/the-next-generation-operating-model-for-the-digital-world

Mc Kinsey (2017b). A road map for digitizing source-to-pay. Retrieved on August 16, 2020, from https://www.mckinsey.com/ /media/mckinsey/business\%20functions/mckinsey\%20digital/our \%20insights/introducing\%20the\%20next-generation\%20operating\%20model/introducing-thenext-gen-operating-model.ashx

Mc Kinsey (2018). A next-generation operating model for source-to-pay. Retrieved on August 17, 2020, from https://www.mckinsey.com/business-functions/operations/our-insights/a-nextgeneration-operating-model-for-source-to-pay

Medini, K. \& Bourey, J. (2012). SCOR-based enterprise architecture methodology. International Journal of Computer Integrated Manufacturing, 25(7), 594-607. Doi: 10.1080/0951192X.2011.646312

Millet, P., Schmitt, P., \& Botta-Genoulaz, V. (2009). The SCOR model for the alignment of business processes and information systems. Enterprise Information Systems, 3 (4). Doi: https://doi.org/10.1080/17517570903030833

The Ministry of Economy, Energy and Business Environment (2020). Romania's Business Service Sector IT\&C, SSC \& BPO. Retrieved on September 15, 2020, from http://investromania.gov.ro/web/wp-content/uploads/2020/08/InvestRomania-ITC_BPOSSC_EN.pdf

Okungbowa, A. (2015). Integration of FI with Other SAP ERP Modules. In: SAP ERP Financial Accounting and Controlling. Berkeley, CA: Apress.

O’Brian, J. (2012). Category Management in Purchasing: A Strategic Approach to Maximize Business Profitability. London, United Kingdom: Kogan Page.

Oracle (2013). My 15 Year Journey to The Truth. Retrieved on September 15, 2020, from https://blogs.oracle.com/cloud-platform/my-15-year-journey-to-the-truth

Oracle (2016). Enabling the SCOR model with Oracle Supply Chain Management. Retrieved on September 15, 2020, from ttps://slideplayer.com/slide/9090953/

Petrisor, I. \& Cozmiuc, D. (2016). Specific Business Models for Romanian Companies - Shared Services. Procedia: Social and Behavioral Sciences, 221, 151-158. Doi: 10.1016/j.sbspro.2016.05.101

Poluha, R. G. (2016). Planning, Management and Control of Processes in Procurement, Manufacturing, Warehousing and Logistics. Retrieved on August 15, 2020, from https://link.springer.com/chapter/10.1007/978-3-662-48515-6_3

Profit Romania (2019). Gigantul indian Infosys a deschis în București un centru de inovație digitală. Urmează unul de securitate cibernetică. Retrieved on September 19, 2020, from 
https://www.profit.ro/stiri/gigantul-indian-infosys-a-deschis-in-bucuresti-un-centru-deinovatie-digitala-urmeaza-unul-de-securitate-cibernetica-18936531

Project Management Institute (2020). Modelling a supply chain. Retrieved on August 18, 2020, from https://www.pmi.org/learning/library/modeling-supply-chain-operation-reference-4448

Prnewswire (2015). Genpact a Leader in Order-to-Cash and Record-to-Report BPO, According to Everest Group. Retrieved on September 15, 2020, from https://www.prnewswire.com/newsreleases/genpact-a-leader-in-order-to-cash-and-record-to-report-bpo-according-to-everestgroup-300066880.html

PWC (2013). Making the right risk decisions to strengthen operations performance. Retrieved on August 20, 2020, from https://www.pwc.com/gx/en/operations-consulting-services/pdf/pwcand-the-mit-forum-for-

supply-chain-innovation_making-the-right-risk-decisions-to-strengthen-operationsperformance_st-13-0060.pdf

PWC (2015). Business Transformation: PwC Presents Its Viewpoint on the Integration Fabric. Retrieved on August 20, 2020, from https://www.slideshare.net/CAinc/businesstransformation-pwc-presents-its-viewpoint-on-the-integration-fabric

PWC (2017). Agency of the future. Next-generation operating models for marketing agencies. Retrieved on August 20, 2020, from https://www.strategyand.pwc.com/us/en/reports/2017/agency-of-the-future.html

PWC (2020). Flexible back-office operating models. Retrieved on August 20, 2020, from https://www.pwc.lu/en/alternative-investments/flexible-back-office-operating-models.html

Roh, J. (2011). The supply chain management organization within the global firm: a structural change perspective. A dissertation submitted to Michigan State University in partial fulfillment of the requirements for the degree of Doctor of Philosophy Logistics

Sabane, M. (2012). SAP BI/SD/MM/PP integration. Retrieved on August 20, 2020, from https://www.slideshare.net/MayurSabane/intro-to-sapsdmmpp-integration

SAP Online Guides (2020). SAP SD Introduction. Retrieved on September 05, 2020, from http://saponlineguides.blogspot.com/p/sap-sd-introduction.html

SAP Online Training (2020). SAP Sales and Distribution. Retrieved on September 05, 2020, from https://saponlinetrg.wordpress.com/sd/

SAP Community Wiki (2014). ERP SD. Retrieved on September 05, 2020, from https://wiki.scn.sap.com/wiki/display/ERPLO/ERP+SD

SAP Tutorials (2020a). Learn SAP MM management. Retrieved on September 05, 2020 from https://www.tutorialspoint.com/sap_mm/sap_mm_overview.htm\#: :text=SAP\%20MM\%20is\% 20the\%20short,procurement\%20activities\%20of\%20an\%20organization.

SAP Tutorials (2020b). Learn SAP SD. Retrieved on September 05, 2020, from https://www.tutorialspoint.com/sap_sd/sap_sd_introduction.htm\#: :text=SAP\%20Sales\%20an d\%20Distribution\%20module,SAP\%20Material\%20Management\%20and\%20PP.

Stewart, G. (1997). Supply-chain operations reference model (SCOR): the first cross-industry framework for integrated supply-chain management, Logistics Information Management, 10 (2)

Supply Chain Council (2010). Supply Chain Operations Reference Model. Retrieved on June 02, 2020, from https://docs.huihoo.com/scm/supply-chain-operations-reference-model-r11.0.pdf

Software AG (2016). Supply Chain Optimization with SCOR BPM Accelerator Powered by ARIS. $\begin{array}{lllll}\text { Retrieved on } & \text { September } & \text { 15, 2020, from }\end{array}$ https://www.softwareag.com/corporate/images/SAG_APICS-SCC_FS_Nov16_tcm389167455.pdf

Supply Chain Digital (2020). Genpact: Agility through Procure-to-Pay (P2P) Solutions. Retrieved on September 18, 2020, from https://www.supplychaindigital.com/procurement/genpactagility-through-procure-pay-p2p-solutions

Supply Chain Management Review (2020). Procurement \& Sourcing. Retrieved on June 02, 2020, from https://. www.scmr.com/topic/category/procurement 
Tata Consultancy Services (2020). TCS Recognized as a 'Leader' in Order-to-Cash (O2C) and Record-to-Report (R2R) BPS by Everest Group. Retrieved on September 18, 2020, from https://www.tcs.com/tcs-leader-o2c-r2r-bps-everest-group

Tech Target (2020). What is supply chain management (SCM) and why is it important?. Retrieved on June 02, 2020, from https://searcherp.techtarget.com/definition/supply-chain-managementSCM

ToughNickel (2020). SAP Order-to-Cash Cycle-FI-SD Integration and Configuration. Retrieved on September 03, 2020, from https://toughnickel.com/business/SAP-Order-To-Cash-SAP-OTC

Trienekens, J. (2008). Architectural frameworks for business information system analysis and design. Lean Business Systems and Beyond, Boston, MA: Springer.

Von Haartman, R. \& Bengtsson, L. (2015). The impact of global purchasing and supplier integration on product innovation. International Journal of Operations \& Production Management, 35(9)

Wang, W. Y. C., Chan, H. K., \& Pauleen, D., J. (2009). Aligning Business Process Reengineering in Implementing Global Supply Chain Systems by the SCOR Model. International Journal of Production Research, 48 (19), 5643-5665. Doi: 10.1080/0020754090316809.

Wholidisapforhire (2020). SAP Organization Structure by Functional Module. Retrieved on August 26, 2020, from https://wholidisapforhire.wordpress.com/sap-organization-structure-byfunctional-module/

Wipro (2020a). Accounts Payable with Bulgarian. Retrieved on October 02, 2020, from https://www.ejobs.ro/user/locuri-de-munca/accounts-payable-with-bulgarian/1326592

Wipro (2020b). Finance and Accounting BpaaS. Retrieved on October 02, 2020, from https://www.wipro.com/cloud/finance-and-accounting-bpaas/

Wipro (2020c). Finance Enterprise Performance Management: Transforming Finance Treasury and Tax Reporting. Retrieved on October 02, 2020, from https://www.wipro.com/consulting/finance-enterprise-performance-management-transforming-finance-/

Wikimedia Commons (2020). B-pack P2P cycle. Retrieved on September 05, 2020, from https://commons.wikimedia.org/wiki/File:B-pack_P2P_cycle.png

Ward, N. H. \& Handfield, R. B. (2006). Dynamics of Breakthrough Supply Management. Retrieved on August 25, 2020, from https://www.researchgate.net/figure/The-SCM-ManagementProcesses-and-the-Supply-Chain-Operations-Reference-Model-SCOR-60_fig1_237567585

Wordpress (2020). Procure To Pay Software Market Future Growth with Technology and Outlook 2020 to 2027 | WNS, Capgemini, IBM, Wipro, and HCL. Retrieved on September 21, 2020, from https://primefeed.in/news/572133/procure-to-pay-software-market-future-growth-withtechnology-and-outlook-2020-to-2027-wns-capgemini-ibm-wipro-and-hcl/

Zgaya, H. \& Hammadi, S. (2016). Logistics engineering. Logistics Engineering and Health. ISTE Press - Elsevier 